\title{
Pneumoperitoneum, Pneumomediastinum and Subcutaneous Emphysema Following Diagnostic Colonoscopy
}

\author{
Pneumoperitoneu, Pneumomediastino e Enfisema Subcutâneo Após \\ Colonoscopia Diagnóstica
}

Antonio Palomeque JIMÉNEZ11, Cristina González PUGA ${ }^{1}$, Beatriz Pérez CABRERA ${ }^{1}$

Acta Med Port 2015 Jan-Feb;28(1):128-128

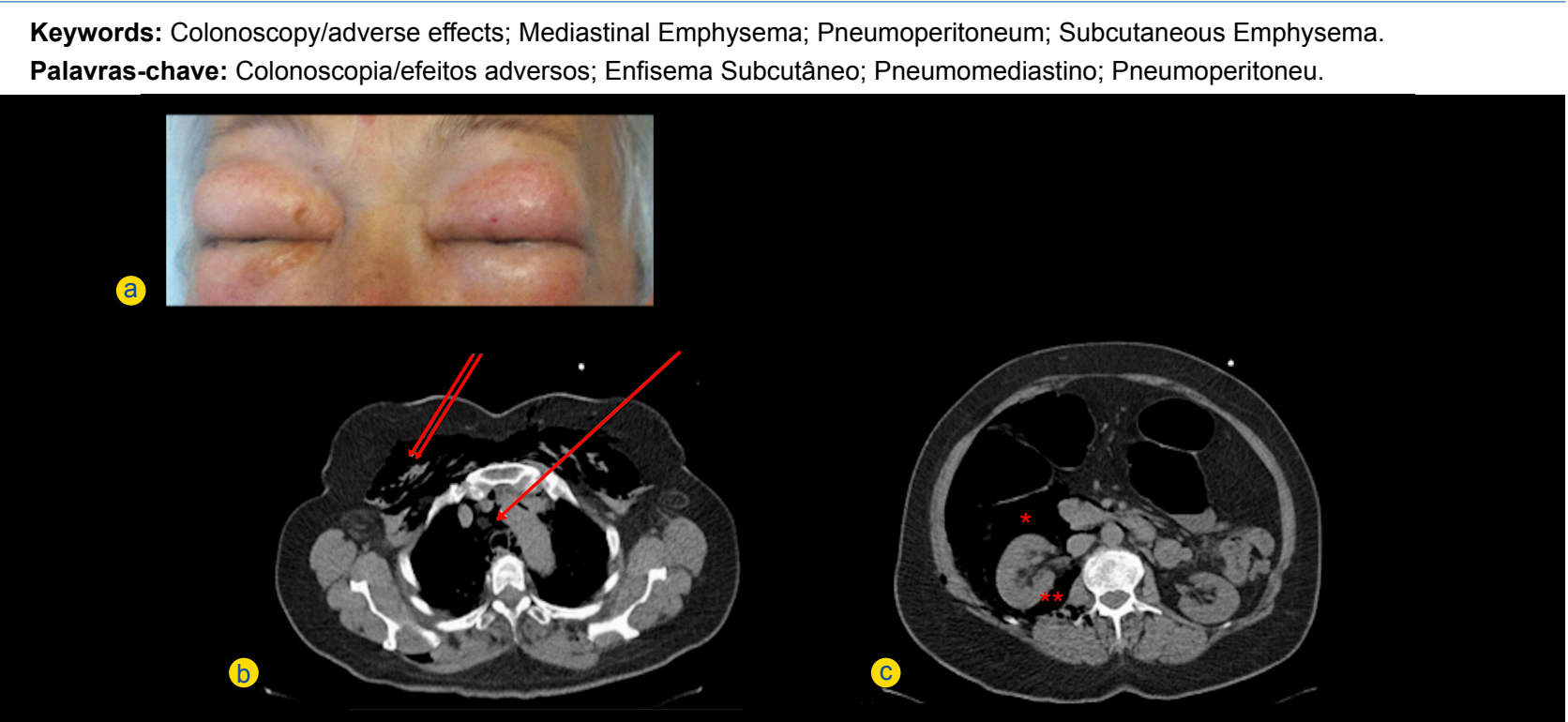

Figure 1 - a) Patient with emphysema in the face and eyelids. b) Chest CT scans where you can see pneumomediastinum (arrow) and subcutaneous emphysema (double arrow). c) Abdominal CT scans where you can see pneumoperitoneum $\left({ }^{*}\right)$ and retropneumoperitoneum (**).

A 60 year-old woman was undergoing a screening colonoscopy for colon cancer. During the colonoscopy, the patient had abdominal pain and emphysema in the face and eyelids (Fig. 1). Abdominal and chest CT scan showed a massive pneumoperitoneum, retropneumoperitoneum, pneumomediastinum and subcutaneous emphysema (Fig. 2). Laboratory tests were normal. The poor clinical status of patients with diffuse peritoneal irritation signs and hemodynamic instability contributed to perform surgery two hours after colonoscopy. A $1 \mathrm{~cm}$ perforation near the rectosigmoid junction was identified, without diffuse peritonitis. Primary closure of the perforation was performed. The patient progressed satisfactorily, without complications, and was discharged after 8 days.

Colonoscopy is a common and safe diagnostic and curative procedure. The incidence of perforation is 0.19 to $0.21 \%$ and usually happens after therapeutic procedures. ${ }^{1}$ Sigmoid colon is frequently involved. Pneumomediastinum and subcutaneous emphysema occurs in exceptional cases. $^{2}$

The choice to perform conservative treatment or endoscopic clipping ${ }^{3-5}$ is determined by good patient condition and absence of signs of peritonitis. Surgical treatment is indicated when patient condition is poor, or has peritonitis signs. ${ }^{1,2,4,5}$

\section{REFERENCES}

1. Cirt N, de Lajarte-ThirouardAS, Olivié D, Pagenault M, Bretagne JF. Emphysème sous-cutané, pneumomédiastin, pneumopéritoine et rétropneumopéritoine dans les suites d'une coloscopie avec mucosectomie. Gastroenterol Clin Biol. 2006;30:779-82.

2. Denadai R, Medeiros CC, Toledo AP, Carvalho AF Jr, Muraco CA. Rectal perforation after colonoscopic polypectomy presented as subcutaneous emphysema, pneumomediastinum and pneumoretroperitoneum successfully treated conservatively in an elderly adult. J Am Geriatr Soc. 2013;61:1433-5.

3. Marwan K, Farmer KC, Varley C, Chapple KS. Pneumothorax, pneumomediastinum, pneumoperitoneum, pneumoretroperitoneum and subcutaneous emphysema following diagnostic colonoscopy. Ann R Coll Surg Engl. 2007;89:20-1.

4. Garcia MT, Ruano A, Galan L, Gay AM, Casal JR. Perforación tras colonoscopia: experiencia en 16 años. Rev Esp Enferm Dig. 2007;99:588-92.

5. Falidas E, Anyfantakis G, Vlachos K, Goudeli C, Stavros B, Villias C. Pneumoperitoneum, retropneumoperitoneum, pneumomediastinum, and diffuse subcutaneous emphysema following diagnostic colonoscopy. Case Rep Surg. 2012;2012:108791.

1. Serviço de Cirurgia. Hospital San Cecilio. Granada. España.

Recebido: 03 de Abril de 2014 - Aceite: 02 de Junho de 2014 | Copyright @ Ordem dos Médicos 2015 


\section{Pneumoperitoneum, Pneumomediastinum and Subcutaneous Emphysema Following Diagnostic Colonoscopy}

Acta Med Port 2015:28:128-128

Publicado pela Acta Médica Portuguesa, a Revista Científica da Ordem dos Médicos

Av. Almirante Gago Coutinho, 151

1749-084 Lisboa, Portugal.

Tel: +351218428 215

E-mail: submissao@actamedicaportuguesa.com

www.actamedicaportuguesa.com

ISSN:0870-399X | e-ISSN: 1646-0758

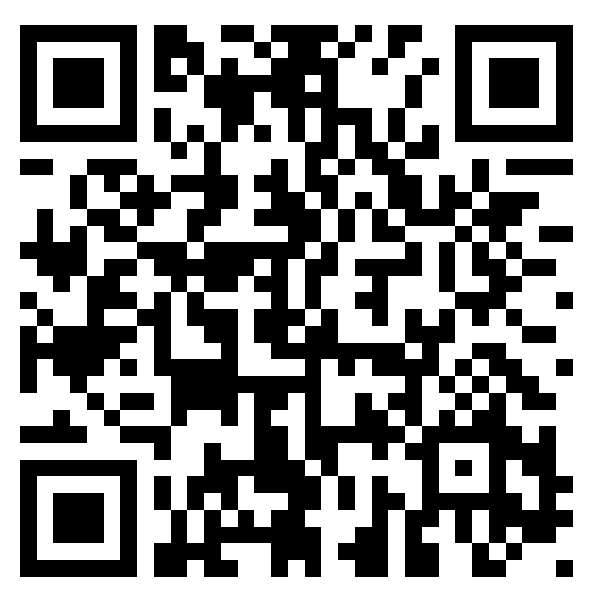

